\title{
Evaluation of MC4R [RS17782313, RS17700633], AGRP [RS3412352] and POMC [RS1042571] polymorphisms with obesity in Northern India
}

\author{
Apurva Srivastava $^{1 *}$, Balraj Mittal ${ }^{3}$, Jai Prakash ${ }^{2}$, Neena Srivastava ${ }^{1}$ \\ From International Conference on Human Genetics and 39th Annual Meeting of the Indian Society of \\ Human Genetics (ISHG) \\ Ahmadabad, India. 23-25 January 2013
}

\section{Background}

Genetic variants of the melanocortin-4 receptor gene (MC4R), agouti related protein (AGRP) and proopiomelanocortin (POMC) are reported to be associated with obesity. Therefore, we examined MC4R rs17782313, MC4R rs17700633, AGRP rs3412352 and POMC rs1042571 for association with obesity in North Indian individuals.

\section{Material and methods}

The variants were investigated for association in 300 individuals with $\mathrm{BMI} \geq 30 \mathrm{~kg} / \mathrm{m}^{2}$ and 300 healthy non-obese individuals with $B M I<30 \mathrm{~kg} / \mathrm{m}^{2}$. The genotyping were analyzed by Taqman probes. The statistical analysis was performed by means of the software SPSS, ver. 19 and $\mathrm{P} \leq 0.05$ was considered statistically significant.

\section{Results}

The genotypes of MC4R rs17782313 and POMC rs1042571 were significantly associated with obesity $\left(\mathrm{BMI} \geq 30 \mathrm{~kg} / \mathrm{m}^{2}\right) \quad(\mathrm{p}=0.02 ; \mathrm{OR}=1.7$ and $\mathrm{p}=0.01 ; \mathrm{OR}=1.6$ respectively). However, MC4R rs17700633 ( $\mathrm{p}=0.001$; $\mathrm{OR}=0.55$ ) was associated with low risk. AGRP rs3412352 $(\mathrm{p}=0.93 ; \mathrm{OR}=0.96)$ showed no association with obesity $\left(\mathrm{BMI} \geq 30 \mathrm{~kg} / \mathrm{m}^{2}\right)$ in North Indian individuals.

\section{Conclusions}

The study provides the first report of association of MC4R rs17782313 and POMC rs1042571 that these may have an effect on obesity $\mathrm{BMI} \geq 30 \mathrm{~kg} / \mathrm{m}^{2}$ but MC4R rs 17700633

\footnotetext{
* Correspondence: drneenasrivastava@hotmail.com

'Department of Physiology, King George's Medical University, Lucknow, (U.P), India

Full list of author information is available at the end of the article
}

and AGRP rs34123523 may not have any influence on obesity $\mathrm{BMI} \geq 30 \mathrm{~kg} / \mathrm{m}^{2}$ in North Indian individuals.

\section{Authors' details}

'Department of Physiology, King George's Medical University, Lucknow, (U.P), India. 'Department of Pediatrics, King George's Medical University, Lucknow, (U.P), India. ${ }^{3}$ Department of Medical Genetics, SGPGIMS, Lucknow, (U.P), India.

Published: 21 January 2014

\section{doi:10.1186/1755-8166-7-S1-P104}

Cite this article as: Srivastava et al:: Evaluation of MC4R [RS17782313, RS17700633], AGRP [RS3412352] and POMC [RS1042571]

polymorphisms with obesity in Northern India. Molecular Cytogenetics 2014 7(Suppl 1):P104.
Submit your next manuscript to BioMed Central and take full advantage of:

- Convenient online submission

- Thorough peer review

- No space constraints or color figure charges

- Immediate publication on acceptance

- Inclusion in PubMed, CAS, Scopus and Google Scholar

- Research which is freely available for redistribution
( Biomed Central 